\title{
Ethanol extract from Cnidium monnieri (L.) Cusson induces cell cycle arrest and apoptosis via regulation of the p53-independent pathway in HepG2 and Hep3B hepatocellular carcinoma cells
}

\author{
EUN GYEONG LIM ${ }^{1}$, GUEN TAE KIM ${ }^{1}$, BO MIN KIM ${ }^{1}$, EUN JI KIM ${ }^{1}$, SANG-YONG KIM ${ }^{2}$ and YOUNG MIN KIM ${ }^{1}$ \\ ${ }^{1}$ Department of Biological Sciences and Biotechnology, College of Life Science and Nano Technology, \\ Hannam University, Daejeon 34054; ${ }^{2}$ Department of Food Science and Bio Technology, \\ Shinansan University, Ansan, Gyeonggi-do 425-792, Republic of Korea
}

Received February 15, 2017; Accepted July 12, 2017

DOI: $10.3892 / \mathrm{mmr} .2017 .8183$

\begin{abstract}
Cnidium monnieri (L.) Cusson is a frequently used traditional Chinese medicine that treats gynecological diseases and carbuncles. However, the mechanism of action of $C$. monnieri remains to be fully elucidated. The present study examined the cell cycle arrest and apoptotic effects resulting from ethanol extract of $C$. monnieri (CME) in HepG2 (wild-type p53) and Hep3B (p53-null) hepatocellular carcinoma cells. An MTT assay was used to confirm the anti-proliferative effect of CME. The cells were stained with Hoechst 33342 or propidium iodide. It was demonstrated that proliferation of HepG2 cells was suppressed by CME. Cell cycle arrest occurred in the G1 phase following treatment with $\mathrm{CME}$ and the number of apoptotic bodies was increased. The expression levels of cell cycle-associated proteins, including protein kinase B (Akt), glycogen synthase kinase-3 $\beta$ (GSK-3 $\beta$ ), p53, cyclin E and cyclin-dependent kinase 2 (CDK2) were determined by western blot analysis. The protein levels of phosphorylated (p)-Akt, p-GSK-3 $\beta$, p-MDM2 and cyclin E were decreased, whereas the protein levels of p53, p21 and p-CDK2 (Thr14/Tyr15) were increased following treatment with CME. Furthermore, treatment or co-treatment with LY294002 (phosphoinositide-3-kinase/Akt inhibitor) or Pifithrin- $\alpha$ (p53 inhibitor) with CME resulted in CME-induced G1 arrest which occurred through the p53-independent signaling pathway in hepatocellular carcinoma cells. In conclusion, CME induces G1 arrest and apoptosis via the Akt/GSK-3 $\beta$ signaling pathway
\end{abstract}

Correspondence to: Professor Young Min Kim, Department of Biological Sciences and Biotechnology, College of Life Science and Nano Technology, Hannam University, Yuseong-dero 1646, Daejeon 34054, Republic of Korea

E-mail:kym@hnu.kr

Key words: apoptosis, Akt/GSK-3 $\beta$ signaling pathway, cell cycle arrest, CME, hepatocellular carcinoma cells, p53-independent pathway which is regulated by MDM2-induced degradation of p21, rather than $\mathrm{p} 53$.

\section{Introduction}

Hepatocellular carcinoma (HCC) is the most common cancer worldwide, and it is a major cause of cancer-associated mortality $(1,2)$. HCC occurs due to multifactorial causes such as smoking, alcohol, human hepatitis virus, fatigue and obesity $(3,4)$. The current therapy for HCC includes surgery, chemotherapy and radiotherapy. However, the therapeutic outcomes are unsatisfactory (3). Cancer cells need an energy source such as glucose and lipids for proliferation and division, and then, they spread to another part of the body from the primary site (5). A previous study reported that bioactive compounds from natural plant extracts play a crucial role as potential therapeutic agents (6). Many plant extracts induce anticancer effects such as anti-proliferative and anti-metastatic effects and cell cycle arrest in various cancer cell lines (7-9). Moreover, the anticancer activity of natural plant extracts has been investigated in HepG2 and Hep3B hepatocellular carcinoma cells $(3,10)$.

Protein kinase B (PKB, also known as Akt) plays a significant role in various cellular functions such as cell survival, proliferation and metabolism (11). The phosphorylation of Akt at serine 473 is known to regulate Glycogen Synthase kinase-3 $\beta$ (GSK-3 $\beta$ ) inactivation through phosphorylation of GSK-3 $\beta$ at serine 9 (12). GSK-3 $\beta$ is one of the two GSK-3 isoforms, and it regulates cell growth, differentiation and cell survival (13). Inactive GSK-3 $\beta$ induces MDM2-mediated p53 ubiquitination and degradation (13). Tumor protein p53 (p53) induces cell cycle arrest and apoptosis through transcriptional regulation of $\mathrm{p} 21^{\text {Cip1/Waf } 1}$, Mouse double minute 2 homolog (MDM2) and Bcl-2-associated X protein (Bax) genes, and also regulates the activation of Bak and caspase-3 $(14,15)$. The p21 protein, one of the cyclin-dependent kinases (CDKs), can arrest cell cycle at G1 phase through inhibition of cyclin E-CDK2 complex (16). However, previous studies have suggested that 21 can induce apoptosis and cell cycle arrest via p53-dependent and p53-independent signaling pathways (16-18). 
Cnidium monnieri (L.) Cusson is a well-known Chinese medicinal herb that is commonly used for treating gynecological diseases, carbuncles, ringworm and nephritis (19-21). According to previous study, the ethanol extracts from C. monnieri contains several bioactive compounds such as osthole and xanthotoxol (22). In the present study, we investigated wether ethanol extracts from C. monnieri (CME) have an influence on cell cycle arrest and apoptosis in hepatocellular carcinoma cells. Furthermore, to determine whether CME-induced cell cycle arrest and apoptosis occurred via a p53-dependent or p53-independent mechanism, we confirmed the regulation of Akt/GSK-3 $\beta$ and p53 signaling pathway by CME in HepG2 (wild-type p53) and Hep3B (p53-null) hepatocellular carcinoma cells.

\section{Materials and methods}

Reagent. Cnidium monnieri (L.) Cusson were purchased from Dong Kyung PHARM Co., Ltd. (Seoul, Korea). The $100 \mathrm{~g}$ of CME was soaked in $800 \mathrm{ml}$ of $99.9 \%$ ethanol, and then stirring for $48 \mathrm{~h}$ at room temperature. The extract was filtered through filter paper (qualitative filter paper no. 1; Toyo Roshi Kaisha, Ltd., Tokyo, Japan) and concentrated with a rotary evaporator to remove the ethanol. The ethanol extracts of Cnidium monnieri (L.) Cusson (CME) was dissolved in dimethyl sulfoxide (DMSO; stock solution, $10-100 \mathrm{mg} / \mathrm{ml}$ ) and refrigerated at $-20^{\circ} \mathrm{C}$ for long storage. The final concentration of CME in the culture medium was controlled at 10-100 $\mu \mathrm{g} / \mathrm{ml}$. LY294002 (PI3K/Akt inhibitor) was purchased from Calbiochem (EMD Millipore, Billerica, MA, USA) and Pifithrin- $\alpha$ (p53 inhibitor) was purchased from Sigma-Aldrich (St Louis, MO, USA).

Cell culture. The human hepatocellular carcinoma cell lines HepG2 and Hep3B were obtained from the American Type Culture Collection (ATCC, Rockville, MD, USA). The cells were grown in DMEM medium (Hyclone, Laboratories Inc., Logan, UT, USA) containing $10 \%$ fetal bovine serum and $1 \%$ antibiotics (both Hyclone Laboratories Inc.) at $37^{\circ} \mathrm{C}$ in a $5 \% \mathrm{CO}_{2}$ atmosphere. The cells were suspended by Trypsin-EDTA (Hyclone, Laboratories Inc.) and separated at $1 \times 10^{6}$ cells $/ \mathrm{ml}$ per $100-\mathrm{mm}$ plate, every $48 \mathrm{~h}$.

Determination of cell viability using MTT assay. The cells were seeded at $1 \times 10^{4}$ cells $/ \mathrm{ml}$ in 12 -well plate and incubated for $24 \mathrm{~h}$. Following incubation, the cells were treated with the $\mathrm{CME}(10-100 \mu \mathrm{g} / \mathrm{ml})$ for 24 or $48 \mathrm{~h}$ at $37^{\circ} \mathrm{C}$ in a $5 \% \mathrm{CO}_{2}$ atmosphere. The inhibitor was pre-treated for $30 \mathrm{~min}$ before treating CME. The respective medium was removed, and cells were incubated with $20 \mu \mathrm{l}$ of MTT solution $(5 \mathrm{mg} / \mathrm{ml})$ in phosphate-buffered saline (PBS) for $1 \mathrm{~h}$. Converted purple formazan from MTT was solubilized in dimethyl sulfoxide (DMSO). The absorbance of the solution in each well was determined using a microplate reader (model 680, Bio-Rad Laboratories, Inc., Tokyo, Japan) at $595 \mathrm{~nm}$.

Measurement of cell cycle arrest. The cells were seeded at $1 \times 10^{6}$ cells $/ \mathrm{ml}$ in $60-\mathrm{mm}$ plate and incubated for $24 \mathrm{~h}$. Following incubation, the cells were treated with the CME for $24 \mathrm{~h}$ at $37^{\circ} \mathrm{C}$ in a $5 \% \mathrm{CO}_{2}$ atmosphere. The inhibitor was pre-treated for 30 min before treating CME. Total cells were harvested by trypsinization, collected by centrifugation, washed with $3 \mathrm{ml}$ of PBS (twice). The supernatant was removed and discarded. The pellet were resuspended in $1 \mathrm{ml}$ of cold $70 \%$ ethanol and freezed at $-20^{\circ} \mathrm{C}$ for at least $3 \mathrm{~h}$. Ethanol-fixed cells were centrifuged at $800 \mathrm{x} \mathrm{g}$ for $5 \mathrm{~min}$ and washed with $1 \mathrm{ml}$ of PBS. The supernatant was removed, and ethanol-fixed cells were resuspended $500 \mu \mathrm{l}$ of PBS. The cells were stained with $4 \mu \mathrm{l}$ of PI $(5 \mathrm{mg} / \mathrm{ml})$ and $10 \mu \mathrm{l}$ of RNase $(10 \mathrm{mg} / \mathrm{ml})$ for $20 \mathrm{~min}$ at room temperature. Fluorescence intensity was analyzed using a Flow cytometry-FACS Canto (Becton-Dickinson Biosciences, Drive Frankline Lage, NJ, USA).

Identification of apoptosis by Hoechst 33342. The cells were seeded at $1 \times 10^{4}$ cells $/ \mathrm{ml}$ in 12 -well plate and incubated for $24 \mathrm{~h}$ after put microscope cover glass (Marlenfeld $\mathrm{GmbH} \&$ Co., Lauda-Königshofen, Germany) into well. Following incubation, the cells were treated with the CME $(20,40,60 \mu \mathrm{g} / \mathrm{ml})$ for $24 \mathrm{~h}$ at $37^{\circ} \mathrm{C}$ in a $5 \% \mathrm{CO}_{2}$ atmosphere. After $24 \mathrm{~h}$, the cells were treated with $0.7 \mu \mathrm{M}$ Hoechst 33342 and incubated for $30 \mathrm{~min}$. Cells were fixed with $3.5 \%$ formaldehyde $500 \mu \mathrm{l}$ for $20 \mathrm{~min}$ and then were gently washed thrice with $150 \mu \mathrm{l}$ of PBS for $5 \mathrm{~min}$. Placed $10 \mu \mathrm{l}$ of the mounting solution (50\% glycerol) on a slide glass and covered with a cover glass. The chromatin was observed using fluorescence microscope (magnification, x200; Axioskop 50, Carl Zeiss, Thornwood, NY, USA).

Western blot analysis. The cells were seeded at $1 \times 10^{5}$ cells $/ \mathrm{ml}$ in 6-well plate and incubated for $24 \mathrm{~h}$. Then, the cells were treated with the concentration of CME for $24 \mathrm{~h}$ at $37^{\circ} \mathrm{C}$ in a $5 \% \mathrm{CO}_{2}$ atmosphere. The inhibitor was pre-treated for $30 \mathrm{~min}$ before treating CME. The cells were then rinsed twice with ice-cold PBS and scraped with RIPA lysis buffer $(50 \mathrm{mM}$ Tris- $\mathrm{HCl} \mathrm{pH} 8.0,150 \mathrm{mM} \mathrm{NaCl}, 1 \% \mathrm{NP}-40,0.5 \%$ sodium deoxycholate, $1 \mathrm{mM}$ PMSF) and subjected to western blot analysis. Protein quantification was performed by Bradford assay. $30 \mu \mathrm{g}$ of protein was loaded per lane. The Nitrocellulose membranes $(0.45 \mu \mathrm{m}$; cat. no. 10600003; GE Healthcare Life Science, Freiburg, Germany) were blocked with $2 \%$ bovine serum albumin (BSA, Bovogen, Melbourne, Australia) in 1X TBST ( 24.7 mM Tris-HCl, pH 8.0, $137 \mathrm{mM} \mathrm{NaCl}, 0.05 \%$ Tween-20) for $1 \mathrm{~h} 30 \mathrm{~min}$ and incubated overnight at $4^{\circ} \mathrm{C}$ with primary antibodies targeting mouse monoclonal-p-Akt (Ser473) (1:2,000; cat. no. 4051), rabbit monoclonal-Akt (1:1,000; cat. no. 4685), rabbit monoclonal-GSK-3 $\beta$ (1:1,000; cat. no. 9315), rabbit monoclonal-Bax (1:1,000; cat. no. 5023), rabbit monoclonal-Bak (1:1,000; cat. no. 6947), rabbit monoclonal-caspase-3 (1:1,000; cat. no. 9665), rabbit polyclonal-Bcl-2 (1:2,000; cat. no. 2876), and rabbit polyclonal- $\beta$-actin $(1: 2,000$; cat. no. 4967); all purchased from Cell Signaling Technology, Inc. (Beverly, MA, USA) and rabbit polyclonal-p-MDM2 (Ser166) (1:3,000; cat.no. ab131355), rabbit monoclonal-MDM2 (1:3,000; cat. no. ab178938), rabbit monoclonal-p21 (1:3,000; cat. no. ab109520), mouse monoclonal-cyclin E (1:3,000; cat. no. ab3927), rabbit monoclonal-p-cdk2 (Tyr15) (1:3,000; cat. no. ab76146), and rabbit monoclonal-p-cdk2 (Thr14) (1:3,000; cat. no. ab68265); all purchased from Abcam Inc. (Cambridge, MA, USA) and rabbit polyclonal-p-GSK-3 $\beta$ (Ser9) (1:1,000; cat. no. sc-11757-R), and mouse monoclonal-p53 (1:1,000; cat. no. sc-126) were purchased from Santa Cruz Inc. (Santa Cruz, CA, USA). After primary antibody incubation, the membranes 


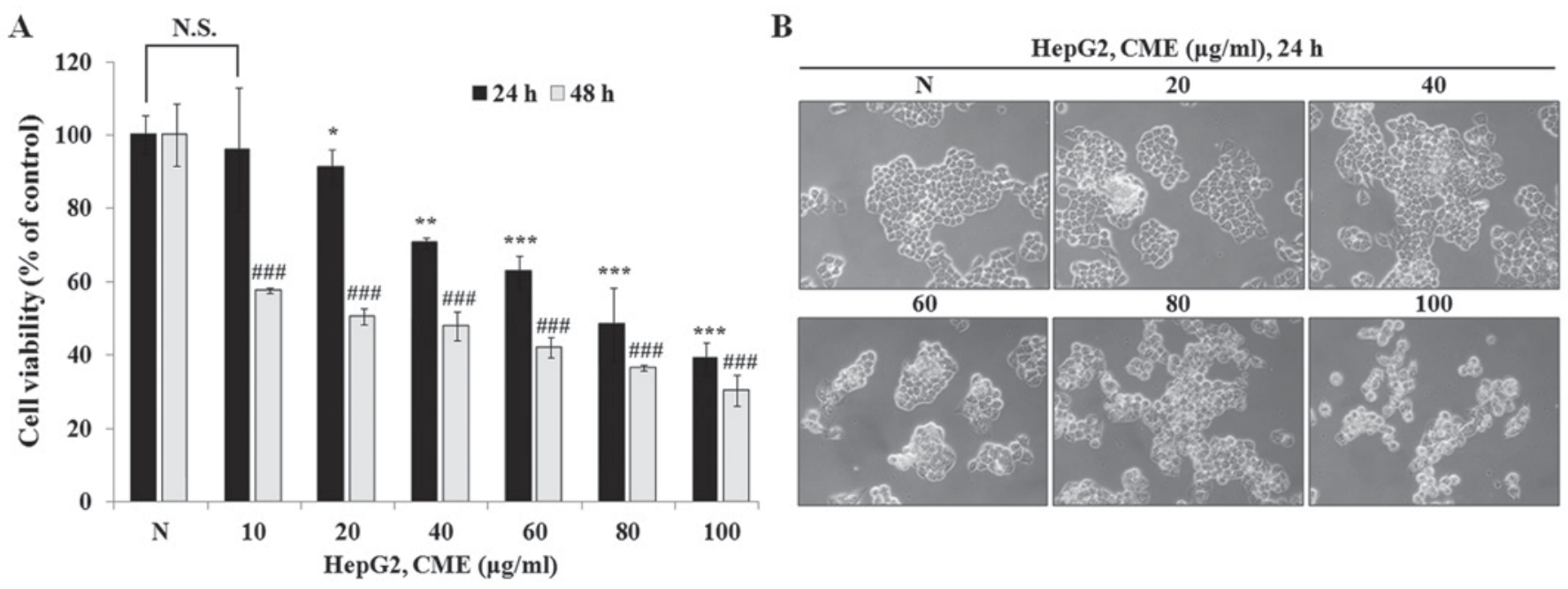

Figure 1. Anti-proliferation and morphological change effects of CME in HepG2 cells. (A) Cell were treated with variable concentrations of CME (10-100 $\mu \mathrm{g} / \mathrm{ml})$ for $24 \mathrm{~h}$ and $48 \mathrm{~h}$. Cell viability was measured by MTT assay. The statistical analysis of the data was carried out by use of an independent sample t-test. "P<0.05, ${ }^{* *} \mathrm{P}<0.01$ and ${ }^{* * *} \mathrm{P}<0.001$ vs. con $(24 \mathrm{~h}) .{ }^{\# \# /} \mathrm{P}<0.001$ vs. con $(48 \mathrm{~h})$ (each experiment, $\mathrm{n}=3$ ). (B) The cell morphology change after treatment of CME. Origin magnification, x200. NS, not significant; CME, Cnidium monnieri (L.) Cusson extract; con, control.

were washed 4 times for 5 min each with $1 \mathrm{X}$ TBST at room temperature. Following the addition of the secondary antibody; goat polyclonal-anti-mouse antibody conjugated with HRP (1:10,000; cat. no. PA1-30126; Thermo Scientific Rockford, IL, USA) and goat anti-rabbit antibody conjugated with HRP (1:10,000; cat. no. 166-2408; Bio-Rad Laboratories, Inc., Tokyo, Japan), the membrane were reacted for $1 \mathrm{~h} 30 \mathrm{~min}$ at room temperature with gentle agitation. After secondary antibody incubation, the membranes were washed 4 times for 10 min each with $1 \mathrm{X}$ TBST at room temperature. Proteins were detected using SuperSignal West Pico Chemiluminescent Substrate (cat. no. PI34080; Thermo Scientific Rockford, IL, USA) and visualized on CP-BU new X-ray film (Agfa HealthCare, Inc., Mortsel, Belgium).

Statistics. MTT assay were statistically analyzed using an unpaired an independent sample t-test (IBM SPSS Statistics 20.0, SPSS Inc., Chicago, IL, USA). A value of $\mathrm{P}<0.05$ was considered to indicate a statistically significant difference.

\section{Results}

CME treatment suppresses cell proliferation and induces cell morphology change in HepG2 cells. To determine the anti-proliferative effect of CME, we performed MTT assay after treatment with various concentrations of CME $(10-100 \mu \mathrm{g} / \mathrm{ml})$ for 24 and $48 \mathrm{~h}$ in HepG2 cells. As shown in Fig. 1A, CME inhibited cell proliferation in a dose-dependent manner (IC50 value $=88.76 \mu \mathrm{g} / \mathrm{ml}$ in $24 \mathrm{~h}$ and $30.93 \mu \mathrm{g} / \mathrm{ml}$ in $48 \mathrm{~h}$ ). Also, we observed the cell morphology change after treatment with CME for $24 \mathrm{~h}$. As shown in Fig. 1B, cell morphology was changed by CME in a dose-dependent manner. Cell shrinkage and loss of proliferation potential were increased when cells were treated with CME (20-100 $\mu \mathrm{g} / \mathrm{ml})$. Furthermore, we confirmed that the number of cells that were detached from the cell culture plate was increased. These characteristics were observed during the process of apoptosis. These results indicated that CME has anti-proliferative and cell morphology change-inducing effects in HepG2 hepatoma cells.

CME treatment induces apoptosis in HepG2 cells. To identify whether CME-induced effects on cell growth and morphology were caused by apoptosis, we performed Hoechst 33342 staining and western blot analysis. As a result, the apoptotic DNA fragmentation was increased by CME in a dose-dependent manner (Fig. 2A). Also, the expression levels of apoptosis-associated proteins, Bax and Bak, were increased and the levels of procaspase- 3 and anti-apoptotic protein Bcl-2 were decreased by CME (Fig. 2B-D).

CME treatment induces cell cycle arrest at G1 phase. To confirm whether the reduced cell viability was due to cell cycle arrest, we analyzed the cell cycle after treatment with various concentrations of CME $(20-60 \mu \mathrm{g} / \mathrm{ml})$ for $6 \mathrm{~h}$. As indicated in Fig. 3, the percentage of G1 phase in HepG2 cells was increased to $54.87 \%$ (control group), 57.94\% (20 $\mu \mathrm{g} / \mathrm{ml}$ ), $61.17 \%(40 \mu \mathrm{g} / \mathrm{ml})$ and $65.41 \%(60 \mu \mathrm{g} / \mathrm{ml})$.

CME treatment regulates the expression levels of cell cycle-related proteins in HepG2 cells. We examined the effect of CME on the expression levels of cell cycle-related proteins by CME using western blot analysis. The results showed that the expression levels of p-Akt, p-GSK-3 $\beta, \mathrm{p}-\mathrm{MDM} 2$ and cyclin $\mathrm{E}$ were decreased, while the levels of $\mathrm{p} 53, \mathrm{p} 21, \mathrm{p}-\mathrm{CDK} 2$ (T14) and p-CDK2 (Y15) were increased in a dose-dependent manner (Fig. 4).

CME-induced apoptosis and cell cycle arrest were occurred through regulation of Akt/GSK-3 $\beta$ signaling pathway in a p53-independent manner. To determine the association between CME-induced apoptosis and cell cycle arrest and the Akt/p53 signaling pathway, we used specific inhibitors such as LY294002 (PI3K/Akt inhibitor) and pifithrin- $\alpha$ (p53 inhibitor). We co-treated the cells with LY294002 or pifithrin- $\alpha$ and CME and performed the MTT assay. As 
A

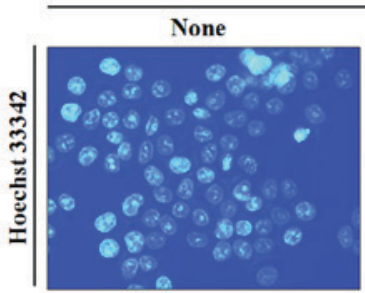

HepG2, CME $(\mu \mathrm{g} / \mathrm{ml}), 24 \mathrm{~h}$
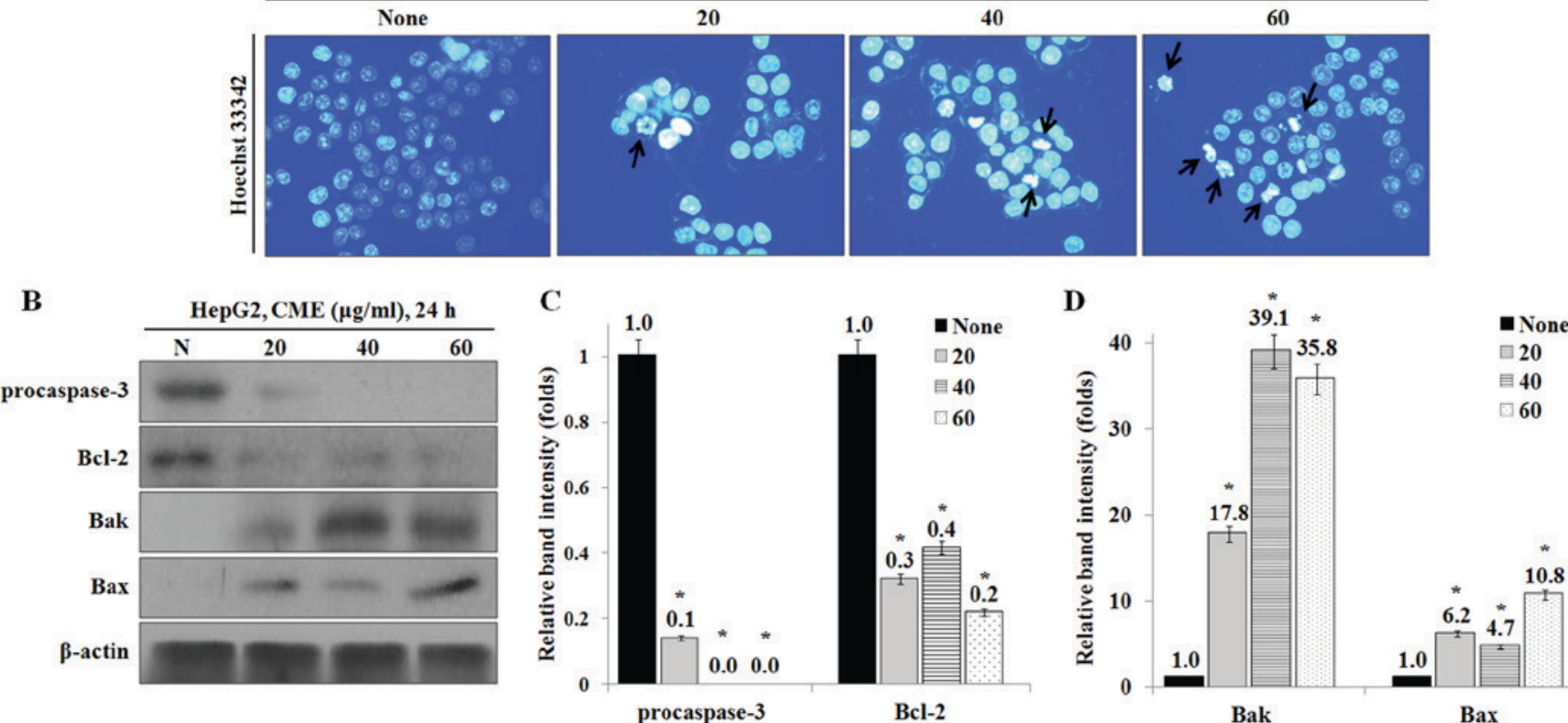

Bak

Bax

Figure 2. CME treatment induces apoptotic DNA fragmentation and regulating expression of mitochondria-mediated apoptotic proteins in HepG2 cells. Cells were treated to with variable concentrations of CME $(20-60 \mu \mathrm{g} / \mathrm{ml})$ for $24 \mathrm{~h}$ (A) Apoptotic bodies were measured by Hoechst 33342 staining. The chromatin was observed using fluorescence microscope (magnification x200). (B) CME effects on pro-caspase-3, Bcl-2, Bak and Bax in HepG2 cells. (C and D) Relative band intensity of mitochondria-mediated apoptotic proteins. The statistical analysis of the data was carried out by use of an independent sample t-test. ${ }^{*} \mathrm{P}<0.001$ vs. con (each experiment, n=3). CME, Cnidium monnieri (L.) Cusson extract; Bcl-2, B-cell lymphoma 2; Bak, Bcl-2-homologous antagonist killer; Bax; Bcl-2-associated X protein con, control.

A

HepG2, CME $(\mu \mathrm{g} / \mathrm{ml}), 24 \mathrm{~h}$
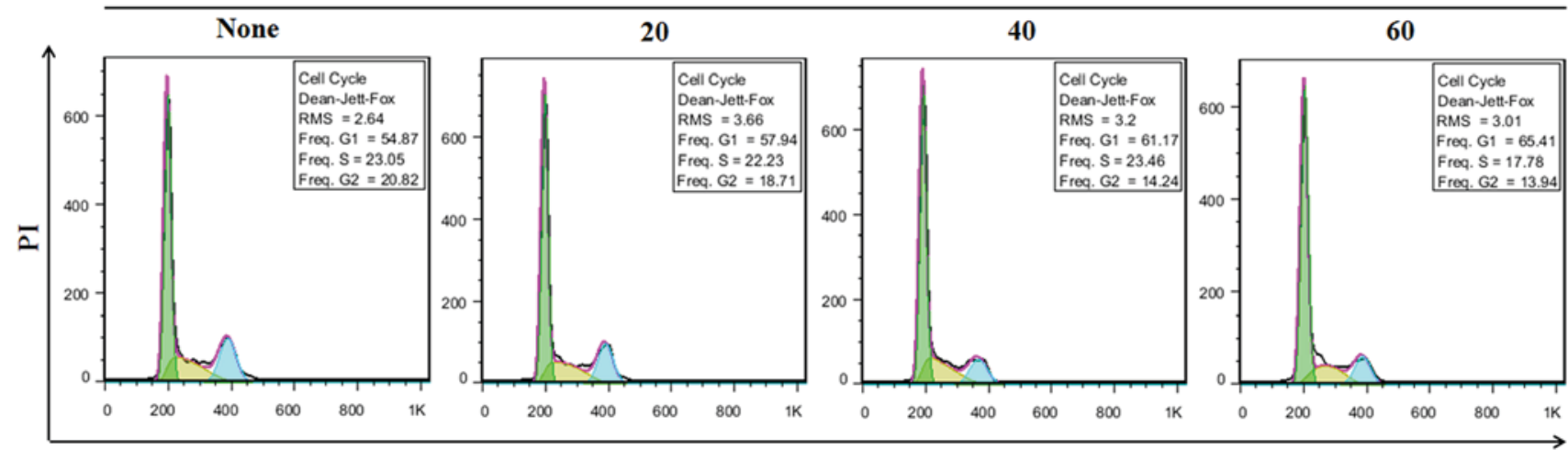

DNA content
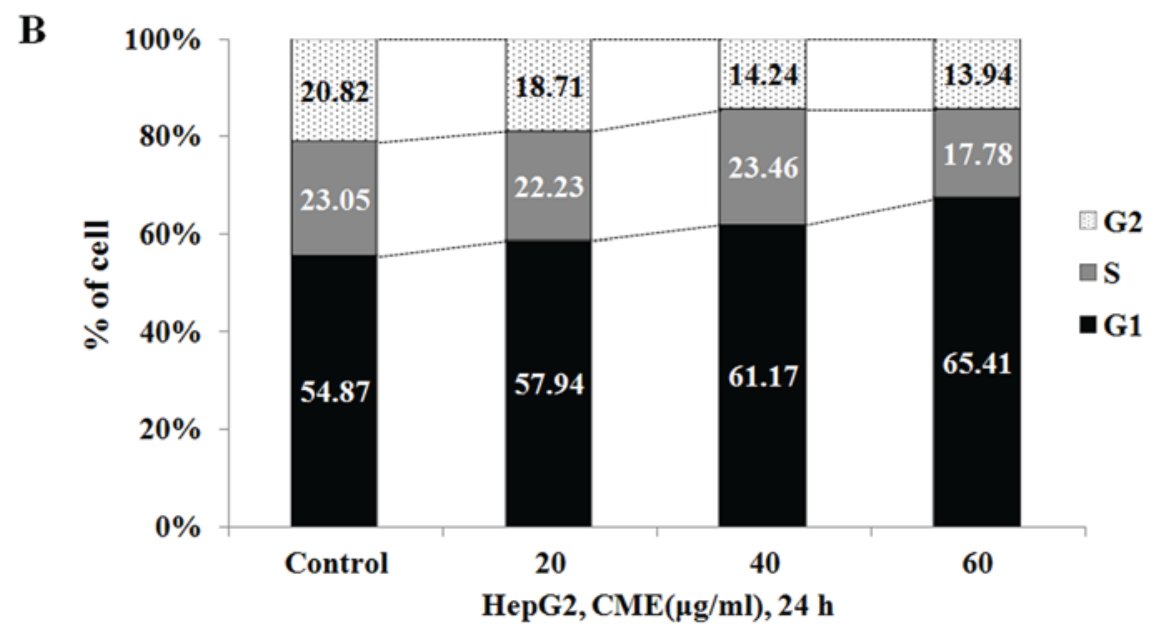

Figure 3. CME treatment induces cell cycle arrest at G1 phase in HepG2 cells. (A) Cells were treated 20-60 $\mu \mathrm{g} / \mathrm{ml}$ of CME for $6 \mathrm{~h}$. CME occurs cell cycle arrest at G1 phase. Cell cycle arrest effect was measured by flow cytometric. (B) The graph of cells ratio at each phases. CME, Cnidium monnieri (L.) Cusson extract. 

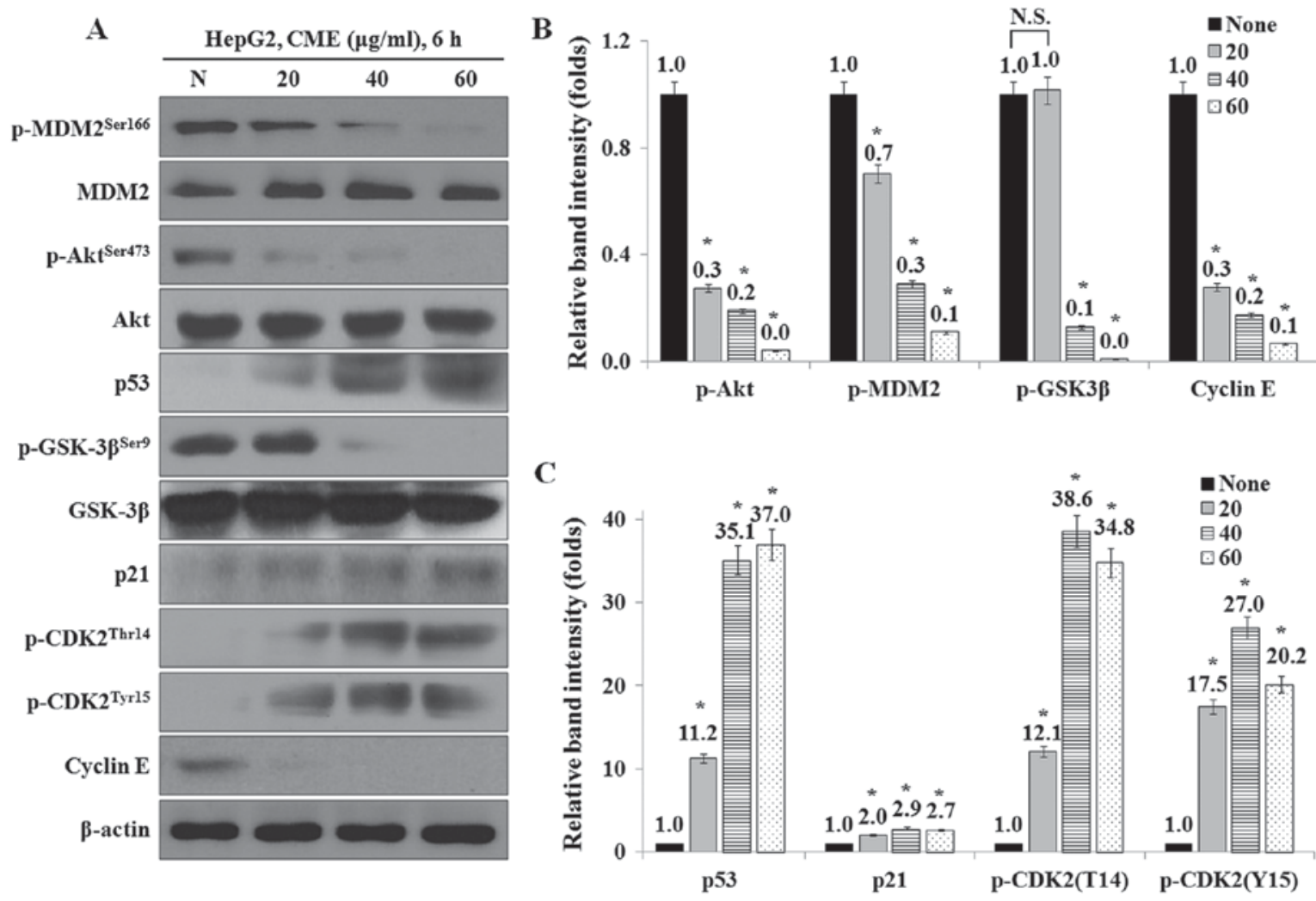

Figure 4. CME treatment regulates the expression levels of cell cycle-mediated proteins in HepG2 cells. (A) CME effects on p-Akt, p-GSK-3 $\beta$, p-MDM2, p53, p21, p-CDK2 (Thr14), p-CDK2 (Tyr15) and cyclin E. Cells were treated 20-60 $\mu \mathrm{g} / \mathrm{ml}$ of CME for $6 \mathrm{~h}$. Protein levels were determined by Western blot analysis. The $\beta$-actin probe served as protein-loading control. (B and C) Relative band intensity of cell cycle-mediated proteins. The statistical analysis of the data was carried out by use of an independent sample t-test. ${ }^{*} \mathrm{P}<0.001$ vs. con (each experiment, $\mathrm{n}=3$ ). CME, Cnidium monnieri (L.) Cusson extract; $\mathrm{p}$, phosphorylated;

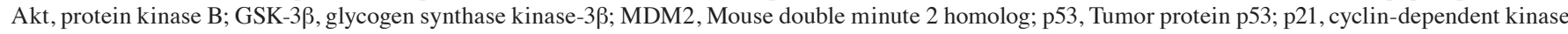
inhibitor 1; CDK2, cyclin-dependent kinase 2.

shown in Fig. 5A, cell viabilities in the CME-treated group and the LY294002-treated group were decreased compared to that in the control group. Also, the cell viability in the CME/LY294002 co-treated group was decreased more than that in the CME-treated group. Furthermore, cell viabilities in the CME/pifithrin- $\alpha$ co-treated group and the CME-treated group did not differ. To confirm whether CME-induced anti-proliferative and apoptotic effects occur in a p53-independent manner, we performed the MTT assay, Hoechst 33342 staining and western blot analysis in Hep3B (p53-null) cells. As a result, CME suppressed Hep3B cell proliferation (Fig. 5B) (IC50 value $=64.46 \mu \mathrm{g} / \mathrm{ml}$ in $24 \mathrm{~h}$ and $46.32 \mu \mathrm{g} / \mathrm{ml}$ in $48 \mathrm{~h}$ ), and induced apoptotic DNA fragmentation in a dose-dependent manner (Fig. 5C). Also, the expression levels of apoptosis-associated proteins were regulated by CME in Hep3B cells (Fig. 5D). In the cell cycle analysis, treatment with CME or LY294002 induced cell cycle arrest at G1 phase and co-treatment with CME/LY294002 and CME/pifithrin- $\alpha$ also induced G1 arrest in HepG2 cells (Fig. 5E). Moreover, the percentage of G1 phase was increased by CME in Hep3B cells (Fig. 5F). These results supported the claim that CME induces apoptosis and G1 cell cycle arrest in a p53-independent manner.

CME treatment induces $G 1$ arrest through regulation of Akt/GSK-3 $\beta$ signaling pathway and increase of $p 21$ expression in a p53-independent manner. To investigate whether the CME-induced cell cycle arrest occurred through p53-independent pathway, we performed western blot analysis after treatment with LY294002 (PI3K/Akt inhibitor) and pifithrin- $\alpha$ (p53 inhibitor). As a result, the expression levels of p-Akt, p-GSK-3 $\beta, \mathrm{p}-\mathrm{MDM} 2$ and cyclin E were decreased in the CME-treated group compared to the control group and the expression levels in the CME/LY294002 co-treated group were also decreased (Fig. 6A). Especially, when we co-treated cells with CME and pifithrin- $\alpha$, the expression levels of p-Akt, p-GSK-3 $\beta$, p-MDM2 and cyclin E were decreased and the expression levels of p53, p21, p-CDK (T14) and p-CDK (Y15) were increased by CME although pifithrin- $\alpha$-treatment was performed. Additionally, the expression levels of cell cycle-related proteins were regulated by CME in Hep3B (p53-null) cells (Fig. 6B).

\section{Discussion}

Chinese medicinal herbs have been used for the treatment of various diseases in China and Southeast Asia (23). Also, many studies have focused on the anticancer effects of phytochemicals which is contained in natural plant (3,7-10). In the present study, we examined whether ethanol extracts from C. monnieri (CME)-induced apoptotic and cell cycle arrest effects were occurred by p53-dependent or p53-independent mechanism in HepG2 (wild-type p53) and Hep3B (p53-null) hepatocellular carcinoma cells. 
A

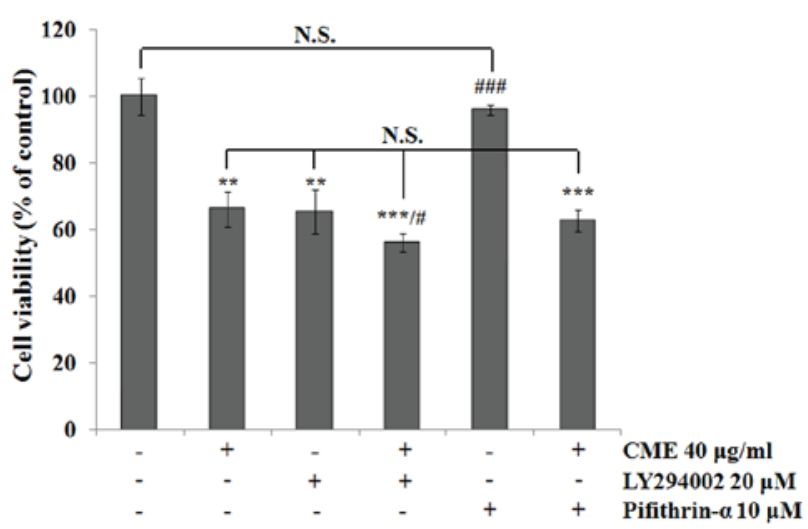

C

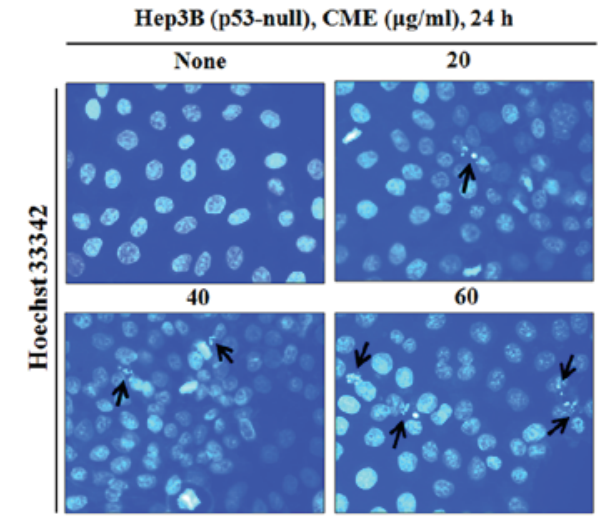

$\mathbf{E}$

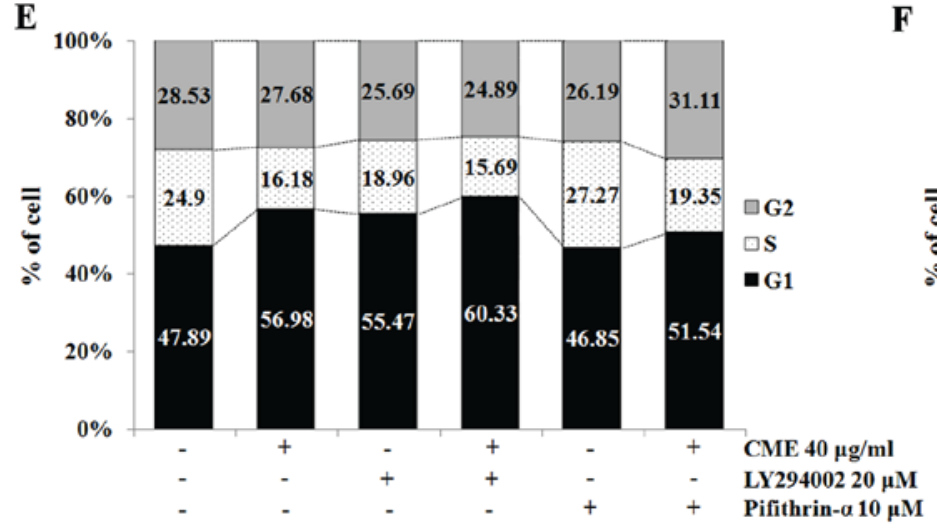

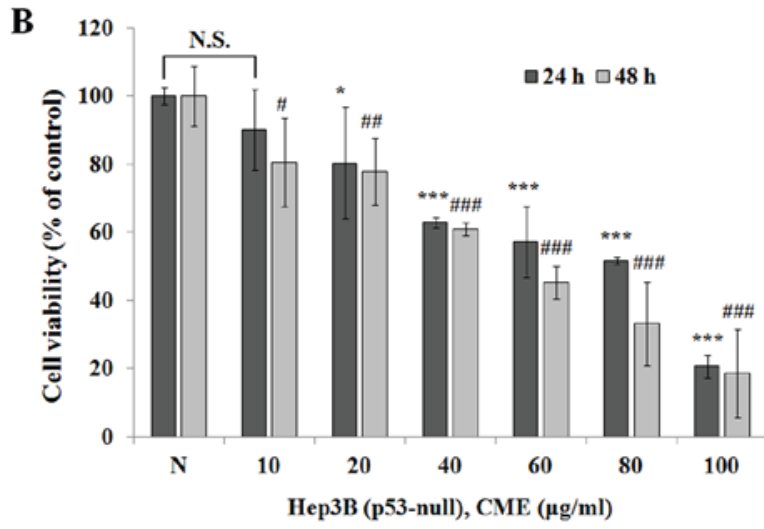

D

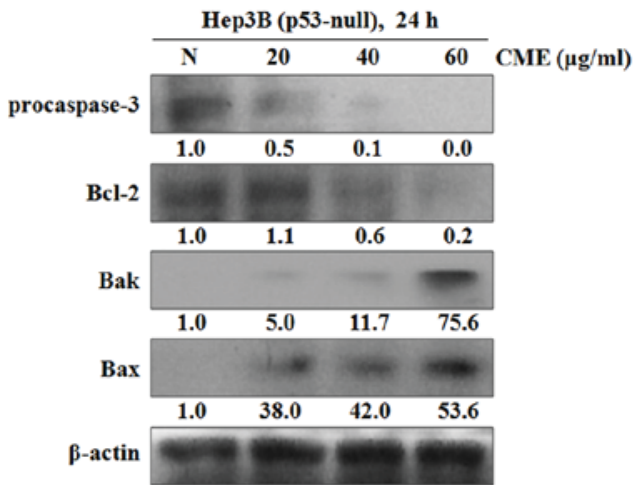

F

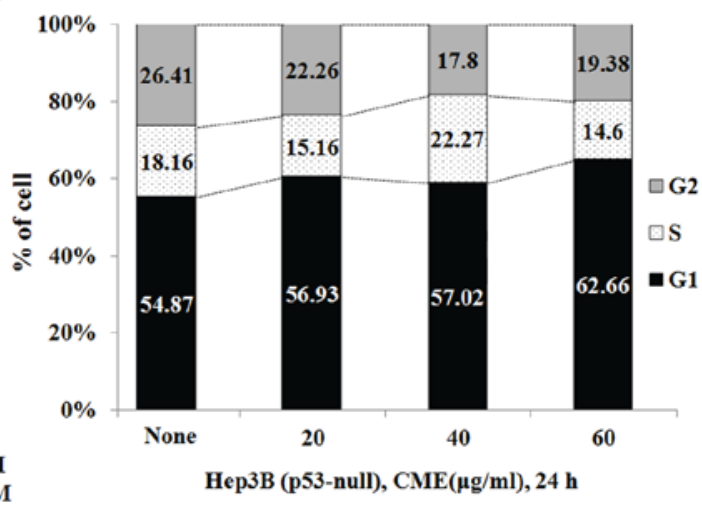

Figure 5. CME induces apoptosis and cell cycle arrest in p53-independent manner in HepG2 and Hep3B cells. Cells were pre-treated with $20 \mu \mathrm{M}$ LY294002 or $10 \mu \mathrm{M}$ Pifithrin- $\alpha$ for $30 \mathrm{~min}$ and co-treated with $40 \mu \mathrm{g} / \mathrm{ml} \mathrm{CME}$ for $24 \mathrm{~h}$ in HepG2 cells. Cells were treated with variable concentrations of CME (10-100 $\mu \mathrm{g} / \mathrm{ml}$ ) for $24 \mathrm{~h}$ and $48 \mathrm{~h}$ in Hep3B cells. (A) Cell viability was measured by MTT assay. The statistical analysis of the data was carried out by use of an independent sample t-test. ${ }^{* *} \mathrm{P}<0.01$ and ${ }^{* * * *} \mathrm{P}<0.001$ vs. con. ${ }^{*} \mathrm{P}<0.05$ and ${ }^{\# \# *} \mathrm{P}<0.001$ vs. $40 \mu \mathrm{g} / \mathrm{ml}$ CME-treated group (each experiment, $\mathrm{n}=3$ ). (B) Measurement of cell viability in Hep3B (p53-null) cells. The statistical analysis of the data was carried out by use of an independent sample t-test. " $\mathrm{P}<0.05$ and ${ }^{* * * *} \mathrm{P}<0.001 \mathrm{vs}$. con (24 h). ${ }^{\#} \mathrm{P}<0.05,{ }^{\# \#} \mathrm{P}<0.01$ and ${ }^{\# \# "} \mathrm{P}<0.001$ vs. con $(48 \mathrm{~h}$ ) (each experiment, $\mathrm{n}=3$ ). (C) Apoptotic bodies were measured by Hoechst 33342 staining. The chromatin was observed using fluorescence microscope (magnification $\mathrm{x} 200$ ). (D) CME regulates expression of mitochondria-mediated apoptotic proteins in p53-independent manner. (E and F) Cell cycle arrest effect was measured by flow cytometric. CME induces G1 cell cycle arrest via p53-independent manner. NS, not significant; CME, Cnidium monnieri (L.) Cusson extract; Bcl-2, B-cell lymphoma 2; Bak, Bcl-2-homologous antagonist killer; Bax; Bcl-2-associated $\mathrm{X}$ protein; con, control.

Preferentially, we confirmed the anti-proliferative effect and cell morphological change induced by CME through the MTT assay and observation of cell morphology. HepG2 cell viability was decreased by CME in a dose- and time-dependent manner (Fig. 1A). Also, when we treated the cells with CME, the cell shrinkage and DNA fragmentation were increased and cell density was decreased in a dose-dependent manner (Fig. 1B). To determine whether the anti-proliferative effect and these characteristics occurred due to apoptosis and cell cycle arrest, we performed Hoechst 33342 staining and cell cycle analysis. Furthermore, we examined the expression levels of apoptosis and cell cycle arrest-associated proteins. In a previous study, the number of apoptotic bodies was increased by natural plant extracts in a dose-dependent manner $(5,6,24)$. Our results showed that $\mathrm{CME}$ induces an increase in the number of apoptotic bodies in a dose-dependent manner (Fig. 2A). The Bcl-2 family, including Bcl-2, Bax and Bak, plays an essential role in mitochondria-dependent apoptosis (25). Bax and Bak activation induces caspase- 3 activity through formation of mitochondrial membrane pore and apoptosome (26). 

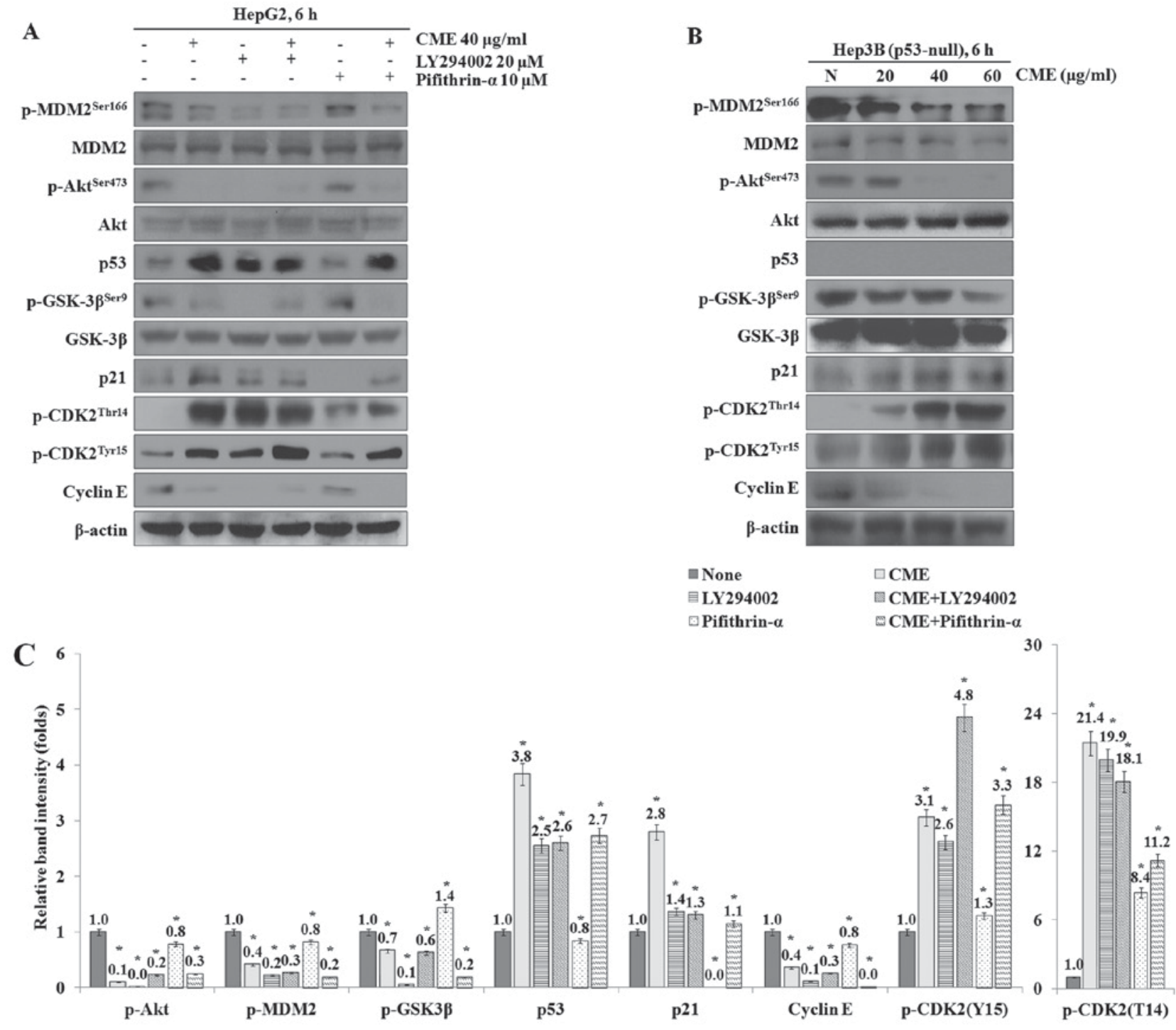

D

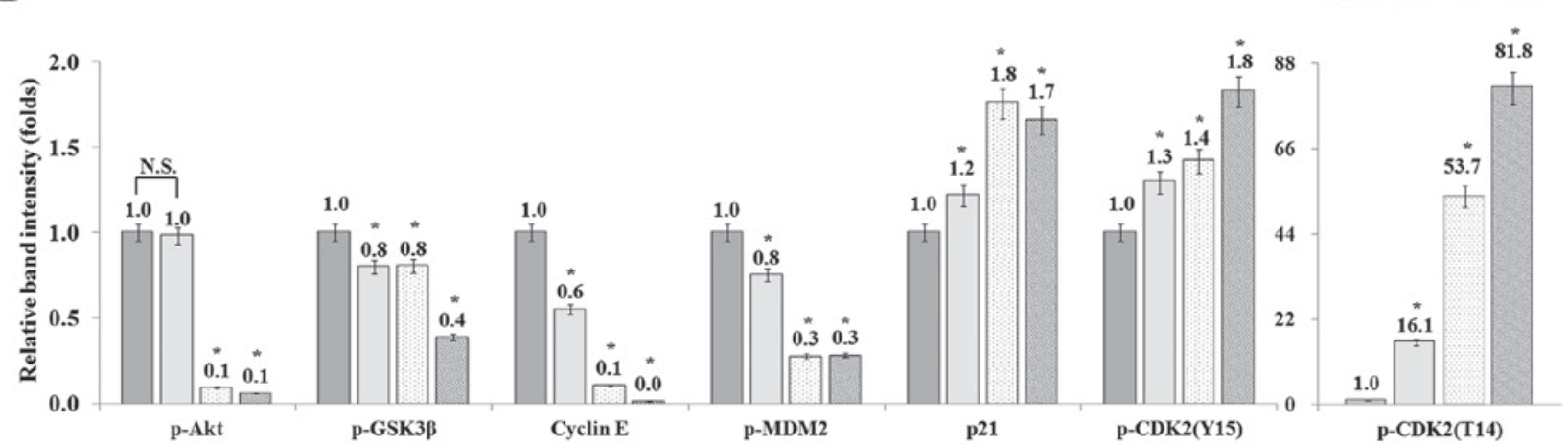

Figure 6. CME induces G1 arrest through regulation of Akt/GSK-3 $\beta$ signaling pathway in p53-independent manner. (A) Co-treatment of LY294002 or Pifithrin- $\alpha$ with CME regulates cell cycle-mediated proteins in HepG2 cells. (B) Cells were treated with variable concentrations of CME (40-60 $\mu \mathrm{g} / \mathrm{ml})$ for $6 \mathrm{~h}$ in Hep3B cells. Protein levels were determined by western blot analysis. The $\beta$-actin probe served as protein-loading control. (C and D) Relative band intensity of cell cycle-mediated proteins in HepG2 (C) and Hep3B (D) cells. The statistical analysis of the data was carried out by use of an independent sample t-test. " $\mathrm{P}<0.001$ vs. con (each experiment, n=3). NS, not significant; CME, Cnidium monnieri (L.) Cusson extract; p, phosphorylated; Akt, protein kinase B; GSK-3 $\beta$, glycogen synthase kinase-3 $\beta$; MDM2, Mouse double minute 2 homolog; p53, tumor protein p53; p21, cyclin-dependent kinase inhibitor 1; CDK2, cyclin-dependent kinase 2.

In our study, we confirmed that CME treatment inhibited the expression of Bcl-2 and pro-caspase- 3 and induced the expression of Bax and Bak proteins (Fig. 2B-D). Additionally, we determined the cell cycle arrest effect of CME by performing cell cycle analysis. When we treated the cells with CME (20-60 $\mu \mathrm{g} / \mathrm{ml})$, the number of G1 phase cells was increased in a dose-dependent manner (Fig. 3). Akt induces inhibition of GSK-3 $\beta$ through phosphorylation at Ser9 (27). Inhibited form 
of GSK-3 $\beta$ regulates p53 ubiquitination by controlling MDM2 phosphorylation $(14,28)$. Activated p53 was translocated to the nucleus and then it induced transcription of $\mathrm{p} 21$ and Bax (15). p21 is a major inhibitor of Cdks which control cell cycle progression (29). Cell cycle at G1 phase is regulated by the cyclin E/CDK2 complex (16). Therefore, we determined the expression levels of cell cycle-related proteins by preforming western blot analysis. As shown in Fig. 4, the protein levels of p-Akt, p-GSK-3 $\beta$, p-MDM2 and cyclin E were decreased and the protein levels of p53, p21, p-CDK2 (Thr14) and p-CDK2 (Tyr15) were increased by CME treatment.

To confirm whether CME induces apoptosis and cell cycle arrest via regulating Akt/p53 signaling pathway, we performed the experiments after pre-treatment with LY294002 (PI3K/Akt inhibitor) and Pifithrin- $\alpha$ (p53 inhibitor). When we treated the cells with LY294002, HepG2 cell viability was decreased compared to that in the control group (Fig. 4A). Also, cell viability in the CME/LY294002 co-treated group was decreased more than that in the CME-treated group and the Pifithrin- $\alpha$-treated group was not significantly different compared to the control group. However, cell viability in the CME/Pifithrin- $\alpha$-co-treated group was decreased similar to that in the CME-treated group. These results suggested that the CME-induced anti-proliferative effect occurred in a $\mathrm{p} 53$-independent manner. Therefore, to determine the role of p53 in the CME-induced anti-proliferative effect, we examined cell viability in Hep3B (p53-null) cells. The results showed that CME treatment reduces cell growth in a dose- and time-dependent manner (Fig. 5B).

Additionally, by performing Hoechst 33342 staining and western blot analysis in Hep3B cells, we determined that CME induces apoptotic DNA fragmentation and regulates the expression of apoptotic proteins (Fig. 5C-D). In the cell cycle analysis, the number of G1 phase cells in the LY294002-treated group and the CME/LY294002 co-treated group was increased in HepG2 cells. Moreover, co-treatment with CME and Pifithrin- $\alpha$ induced G1 cell cycle arrest (Fig. 5E). In Hep3B cells, CME also induced G1 cell cycle arrest (Fig. 5F). Our results determined that CME-induced apoptosis and G1 cell cycle arrest effects occurred in a p53-independent manner.

To investigate the CME-induced G1 cell cycle arrest which occurred via p53-independent signaling pathway, we identified the expression of cell cycle regulation proteins after treatment with CME and LY294002 or Pifithrin- $\alpha$. The results showed that the expression levels of p-Akt, p-GSK-3 $\beta, \mathrm{p}-\mathrm{MDM} 2$ and cyclin $\mathrm{E}$ were decreased and the expression levels of $\mathrm{p} 53, \mathrm{p} 21$, p-CDK2 (Thr14) and p-CDK2 (Tyr15) were increased in the CME/LY294002 and the CME/Pifithrin- $\alpha$ co-treated groups (Fig. 6A and C). Furthermore, cell cycle-related proteins including p-Akt, p-GSK-3 $\beta$, p-MDM2, p21, cyclin E, p-CDK2 (Thr14) and $\mathrm{p}-\mathrm{CDK} 2$ (Tyr15) were regulated except for $\mathrm{p} 53$ protein (Fig. 6B and D). According to a previous study, GSK-3 $\beta$ phosphorylates MDM2 protein and overexpression of MDM2 promotes degradation of $\mathrm{p} 21$ through proteasome-mediated degradation in a p53-independent manner $(30,31)$. Also, many of the studies have reported that natural extracts induce apoptosis and cell cycle arrest through controlling the p53-independent signaling pathway (32-34). Moreover, overexpression of $\mathrm{p} 21$ induces the expression of pro-apoptotic protein Bax and modulates the Bcl-2:Bax ratio in Hep3B cells (35).
In conclusion, CME treatment induces apoptosis and cell cycle arrest at G1 phase in HepG2 and Hep3B hepatocellular carcinoma cells. Also, these anticancer effects occurred through increase of p21 protein expression by Akt/GSK-3ß/MDM2 signaling pathway in a p53-independent manner.

\section{References}

1. Wang Y, Nie H, Zhao X, Qin Y and Gong X: Bicyclol induces cell cycle arrest and autophagy in HepG2 human hepatocellular carcinoma cells through the PI3K/AKT and Ras/Raf/MEK/ERK pathways. BMC Cancer 16: 742, 2016.

2. Sun Y, Tao C, Huang X, He H, Shi H, Zhang Q and Wu H: Metformin induces apoptosis of human hepatocellular carcinoma HepG2 cells by activating an AMPK/p53/miR-23a/FOXA1 pathway. Onco Targets Ther 9: 2845-2853, 2016.

3. Hsu SC, Kuo CL, Lin JP, Lee JH, Lin CC, Su CC, Lin HJ and Chung JG: Crude extracts of Euchresta formosana radix induce cytotoxicity and apoptosis in human hepatocellular carcinoma cell line (Hep3B). Anticancer Res 27: 2415-2425, 2007.

4. Grizzi F, Franceschini B, Hamrick C, Frezza EE, Cobos E and Chiriva-Internati M: Usefulness of cancer-testis antigens as biomarkers for the diagnosis and treatment of hepatocellular carcinoma. J Transl Med 5: 3, 2007.

5. Lee SH, Jung DW, Kim GT, Park SY, Kim SY, Park OJ and Kim YM: Quercetin of plants extracts regulates Sestrin2 and induces apoptosis in HT-29 colon cancer cells. J Cancer Prev 17: 244-250, 2012.

6. Parkash O, Kumar A, Kumar P and Ajeet: Anticancer Potential of Plants and Natural Products: A review. Am J Pharmacol Sci 1: 104-115, 2013.

7. Tai Y, Sun YM, Zou X, Pan Q, Lan YD, Huo Q, Zhu JW, Guo F, Zheng CQ, Wu CZ and Liu H: Effect of polygonatum odoratum extract on human breast cancer MDA-MB-231 cell proliferation and apoptosis. Exp Ther Med 12: 2681-2687, 2016.

8. Park C, Jeong JS, Jeong JW, Kim SO, Kim YJ, Kim GY, Hong SH and Choi YH: Ethanol extract of Kalopanax septemlobus leaf inhibits HepG2 human hepatocellular carcinoma cell proliferation via inducing cell cycle arrest at G1 phase. Asian Pac J Trop Med 9: 344-350, 2016

9. Byambaragchaa M, de la Cruz J, Yang SH and Hwang SG: Anti-metastatic potential of ethanol extract of Saussurea involucrata against hepatic cancer in vitro. Asian Pac J Cancer Prev 14: 5397-5402, 2013

10. Choi EJ and Kim GH: Antioxidant and anticancer activity of Artemisia princeps var. orientalis extract in HepG2 and Hep3B hepatocellular carcinoma cells. Chin J Cancer Res 25: 536-543, 2013.

11. Nicholson KM and Anderson NG: The protein kinase B/Akt signalling pathway in human malignancy cellular signaling. Cell Signal 14: 381-395, 2002.

12. Romorini L, Garate X, Neiman G, Luzzani C, Furmento VA, Guberman AS, Sevlever GE, Scassa ME and Miriuka SG: AKT/GSK $3 \beta$ signaling pathway is critically involved in human pluripotent stem cell survival. Sci Rep 6: 35660, 2016.

13. Thotala DK, Hallahan DE and Yazlovitskaya EM: Glycogen synthase kinase $3 \beta$ inhibitors protect hippocampal neurons from radiation-induced apoptosis by regulating MDM2-p53 pathway. Cell Death Differ 19: 387-396, 2012.

14. Watcharasit P, Bijur GN, Song L, Zhu J, Chen X and Jope RS: Glycogen synthase kinase-3beta (GSK3beta) binds to and promotes the actions of p53. J Biol Chem 278: 48872-48879, 2003.

15. Tan J, Zhuang L, Leong HS, Iyer NG, Liu ET and Yu Q: Pharmacologic Mmodulation of glycogen synthase kinase-3beta promotes $\mathrm{p} 53$-dependent apoptosis through a direct Bax-mediated mitochondrial pathway in colorectal cancer cells. Cancer Res 65: 9012-9020, 2005.

16. Karimian A, Ahmadi Y and Yousefi B: Multiple functions of $\mathrm{p} 21$ in cell cycle, apoptosis and transcriptional regulation after DNA damage. DNA Repair (Amst) 42: 63-71, 2016.

17. Meng J, Zhang HH, Zhou CX, Li C, Zhang F and Mei QB: The histone deacetylase inhibitor trichostatin A induces cell cycle arrest and apoptosis in colorectal cancer cells via p53-dependent and -independent pathways. Oncol Rep 28: 384-388, 2012. 
18. Zhang R, Wang Y, Li J, Jin H, Song S and Huang S: The Chinese herb isolate yuanhuacine (YHL-14) induces G2/M arrest in human cancer cells by up-regulating p21 protein expression through an p53 protein-independent cascade. J Biol Chem 289: 6394-6403, 2014.

19. Jiang G, Liu J, Ren B, Tang Y, Owusu L, Li M, Zhang J, Liu L and Li W: Anti-tumor effects of osthole on ovarian cancer cells in vitro. J Ethnopharmacol 193: 368-376, 2016

20. Yang LL, Wang MC, Chen LG and Wang CC: Cytotoxic activity of coumarins from the fruits of Cnidium monnieri on leukemia cell lines. Planta Med 69: 1091-1095, 2003.

21. Zhu YP: Chinese Material Medica: Chemistry, Pharmacology, and Applications. Harwood Academic Publishers, Amsterdam, p624, 1998

22. Li HB and Chen F: Simultaneous separation and purification of five bioactive coumarins from the Chinese medicinal plant Cnidium monnieri by high-speed counter-current chromatography. J Sep Sci 28: 268-272, 2005.

23. Zhao T, Pan H, Feng Y, Li H and Zhao Y: Petroleum ether extract of Chenopodium album L. prevents cell growth and induces apoptosis of human lung cancer cells. Exp Ther Med 12: 3301-3307, 2016.

24. Wang R, Zhang Q, Peng X, Zhou C, Zhong Y, Chen X, Qiu Y, Jin M, Gong M and Kong D: Stellettin B induces G1 arrest, apoptosis and autophagy in Hhuman non-small cell lung cancer A549 cells via blocking PI3K/Akt/mTOR pathway. Sci Rep 6: 27071, 2016.

25. Chien SY, Wu YC, Chung JG, Yang JS, Lu HF, Tsou MF, Wood WG, Kuo SJ and Chen DR: Quercetin-induced apoptosis acts through mitochondrial- and caspase-3-dependent pathways in human breast cancer MDA-MB-231 cells. Hum Exp Toxicol 28: 493-503, 2009.

26. Degli Esposti M and Dive C: Mitochondrial membrane permeabilisation by Bax/Bak. Biochem Biophys Res Commun 304: 455-461, 2003
27. Rössig L, Badorff C, Holzmann Y, Zeiher AM and Dimmeler S Glycogen synthase kinase-3 couples AKT-dependent signaling to the regulation of p21Cip1 degradation. J Biol Chem 277: 9684-9689, 2002.

28. Kulikov R, Boehme KA and Blattner C: Glycogen synthase kinase 3-dependent phosphorylation of Mdm2 regulates p53 abundance. Mol Cell Biol 25: 7170-7180, 2005.

29. Abbas T and Dutta A: p21 in cancer: Intricate networks and multiple activities. Nat Rev Cancer 9: 400-414, 2009.

30. Zhang Z, Wang H, Li M, Agrawal S, Chen X and Zhang R: MDM2 is a negative regulator of $\mathrm{p} 21 \mathrm{WAF} 1 / \mathrm{CIP} 1$, independent of p53. J Biol Chem 279: 16000-16006, 2004.

31. Sutherland C: What are the bona fide GSK3 substrates? Int J Alzheimers Dis 2011: 505607, 2011.

32. Yuan L, Zhang Y, Xia J, Liu B, Zhang Q, Liu J, Luo L, Peng Z, Song $\mathrm{Z}$ and $\mathrm{Zhu} \mathrm{R}$ : Resveratrol induces cell cycle arrest via a p53-independent pathway in A549 cells. Mol Med Rep 11: 2459-2464, 2015

33. Shen G, Xu C, Chen C, Hebbar V and Kong AN: p53-independent G1 cell cycle arrest of human colon carcinoma cells HT-29 by sulforaphane is associated with induction of p21CIP1 and inhibition of expression of cyclin D1. Cancer Chemother Pharmacol 57: 317-327, 2006.

34. Kim EJ, Kim GT, Kim BM, Lim EG, Kim SY, Ha SH, Kim YM and Yoo JG: Cell cycle arrest effects by artemisia annua linné in Hep3B liver cancer cell. KSBB J 30: 175-181, 2015.

35. Gartel AL and Tyner AL: The role of the cyclin-dependent kinase inhibitor p21 in apoptosis. Mol Cancer Ther 1: 639-649, 2002. 